\title{
Some Stability Parameters in Sunflower (Helianthus annuus L.) Genotypes at Various Environments
}

\author{
A.H. Salem, H.A. Awaad, M.M.A. Ali, A.E.A. Omar and \\ K.Y. Kamal \\ Agronomy Department, Faculty of Agriculture, Zagazig \\ University, Sharkia, Egypt.
}

\begin{abstract}
$\mathbf{Y}$ IELD stability is one of the most important needs in sustainable agriculture. The ideal sunflower (Helianthus annuus L.) genotype would produce high yields when water supply is abundant and should have only small reduction in yields under water stress condition. The use of methods that integrate yield performance and stability to select superior genotypes becomes prerequisite. Phenotypic, genotypic and AMMI stability parameters were computed for seed yield and oil content of twelve sunflower genotypes under six diverse applications (the combination between three water regimes and two seasons). Phenotypic stability parameters indicated that the most desired and stable sunflower genotypes were L20, L235 and L460 for seed yield/fed as well as L20, L350, Giza 102 and Sakha 53 for seed oil content (\%). Genotypic stability estimates revealed that the most average stable genotypes were L20 for seed yield $(\mathrm{t} / \mathrm{fed})$ and L350, L770, Giza 102 and Sakha 53 for seed oil content (\%). According, to AMMI stability, the most stable sunflower genotype was L20, L235 and L460 for seed yield (t/fed) as well as L235, L350 and Giza 102 for seed oil content. Strong agreement was found between Eberhart and Russell, Tai and AMMI statistics for measuring stability parameters for seed yield (t/fed) and seed oil content (\%) in almost sunflower genotypes.
\end{abstract}

Keywords: Sunflower, Drought, Drip irrigation, Stability analysis. Abbreviations: AMMI=additive main effect and multiplicative interaction.

Drought is a serious problem for agriculture all around the world. Sunflower (Helianthus annuus L.) is categorized as a low to medium drought sensitive crop (Rauf, 2008). It has been found that both quantity and distribution of water supply has a significant effect on seed yield and oil content in sunflower (Iqbal et al., 2005). Stability of a genotype over environments is usually tested by its degree of interaction with different growing environments. High mean yield should not be the only criterion for stability of genotype unless its high performance is established over the different environmental conditions (Sial \& Ahmad, 2000).Various statistical techniques have been developed to identify systematic variation in individual genotype response. Among these, Eberhart \&

Emails : zasalem@yahoo.com ; Hassanawaad@yahoo.com; Abd_lhamed@yaoo.com; omaromar1971@yahoo.com and khaled_Agri2@yahoo.com, respectively 
Russell (1966) model which has been widely used in studies of adaptability and phenotypic stability of plant materials. Genotypic stability parameters have been proposed by Tai (1971) to provide information on the real response of genotype to environment. Also, the additive main effects and multiplicative interaction AMMI model (Crossa, 1990) provide a visual inspection and interpretation of genotype $\mathrm{x}$ environment interaction and stability. It separates the additive variance from the multiplicative variance (interaction) and then applies PCA (principal components analysis) to the interaction (residual) portion from the ANOVA (analysis of variance) analysis to extract a new set of co-ordinate axes which account more effectively for the interaction patterns (Cravero et al., 2010).

In this respect, many investigators evaluated performance and stability of oil crop genotypes and found significant GxE interaction for seed yield and oil content with different degrees of stability for sunflower genotypes (Ali et al., 2006, Ghafoor et al., 2005 and Tabrizi, 2012) ; maize (Zea mays, L.) ones (Ali, 2009) and sesame (Sesamum indicum L. ) Awaad \& Ali (2002) and Mekonnen \& Mohammed (2010).

The present investigation was initiated to study the magnitude and nature of GxE interaction and to identify stable genotypes that can give high seed yield and oil content under various levels of water regime.

\section{Materials and Methods}

To assess the phonotypic and genotypic stability, 12 sunflower (Helianthus annuиs L.) genotypes (L38, L20, L11, L8, Giza 102, Sakha 53, L19, L235, L350, L990, L770 and L460) were examined for seed yield and oil content under six different environments, which are the combination between three water regimes (control supplemented by $\left(3000 \mathrm{~m}^{3}\right)$, moderate drought $\left(2000 \mathrm{~m}^{3}\right)$ and severe drought $\left(1000 \mathrm{~m}^{3}\right)$ ) and two summer seasons of 2009 and 2010 at ElKhattara Farm, Faculty of Agriculture, Zagazig University, Egypt. Drip irrigation system was used. Water quantities were adjusted by a water counter for all irrigation treatments. The soil of the experimental site is sandy in texture and had an average $\mathrm{pH}$ of 8.1 and organic matter content of $0.26 \%$; the average available N, P and K contents were 15.1, 3.2 and 90.5 ppm, respectively. Split plot design was used as the main plots were assigned to water regimes, and the subplots for sunflower genotypes with four replications. The sub-plot area was $17.5 \mathrm{~m}^{2}$ (5 m length $\times 3.5 \mathrm{~m}$ width), containing 7 rows, the row distance was $50 \mathrm{~cm}$ and three seeds of sunflower were sown in hills $30 \mathrm{~cm}$ apart on $1^{\text {st }}$ June in both season. After 21 days from sowing, plants were thinned to be one plant / hill. All agricultural practices for sunflower production were practiced as recommended to growers. Data were recorded on seed yield ( $\mathrm{t} / \mathrm{fed}$ ) and seed oil content (\%). Oil content was determined according to Association Official Analytical Chemist (AOAC, 1984) using Soxhlet apparatus and diethyl ether as a solvent. 
Data were statistically analyzed according to Steel \& Torrie (1980). Phenotypic and genotypic stability analyses were computed according to Eberhart \& Russell (1966) and Tai (1971), respectively. Also, additive main effects and multiplicative interaction method (AMMI) was applied according to Purchase (1997), Purchase et al. (2000) and Schoeman (2003).

\section{Results}

Data presented in Table 1 provide the results of the combined analysis of variance for seed yield and seed oil content of twelve sunflower genotypes across six environments (two growing years $x$ three levels of water regime). The results showed that sunflower genotypes $(\mathrm{G})$, growing years $(\mathrm{Y})$, levels of water regime (I) and genotypes $x$ levels of water regime $(\mathrm{G} \times \mathrm{I})$ exhibited highly significant $(\mathrm{P}<0.01)$ values for both seed yield and oil content. Higher magnitude of mean squares for seed yield due to the levels of water regime indicates a great influence of water stress on sunflower seed yield. The analysis of variance for stability for seed yield ( $\mathrm{t} / \mathrm{fed}$ ) and seed oil content (\%) across the six environments (Table 2) showed that each of genotypes, environments and the interaction between them exhibited highly significant values $(\mathrm{P}<0.01)$ for both characters. The partitioning of mean squares (environment + genotype $\mathrm{x}$ environment) showed that environments (linear) differed significantly and were quite diverse with respect to their effects on the performance of sunflower genotypes for both seed yield and oil content. The higher magnitude of mean squares due to environments (linear) as compared to genotype $\mathrm{x}$ environment (linear) revealed that linear response of environments accounted for the major part of total variation of both studied characters. The significance of mean squares due to genotype $\mathrm{x}$ environment (linear) component against pooled deviation for seed yield and oil content suggested that genotypes were diverse for their regression response to change with the environmental fluctuations.

TABLE 1. Combined analysis of variance for seed yield and seed oil content $(\%)$ of 12 sunflower genotypes across 6 environments.

\begin{tabular}{|c|c|c|c|}
\hline Source of variation & d.f. & $\begin{array}{c}\text { Seed yield } \\
\text { (t/fed) }\end{array}$ & $\begin{array}{c}\text { Seed oil } \\
\text { content }(\%)\end{array}$ \\
\hline Reps (Env.) & 18 & 0.016 & $4.928^{* *}$ \\
\hline Genotype (G) & 11 & $1.331^{* * *}$ & $245.176^{* *}$ \\
\hline Year (Y) & 1 & $0.377^{* * *}$ & $37.942^{* *}$ \\
\hline Irrigation (I) & 2 & $8.310^{* *}$ & $141.704^{* *}$ \\
\hline G x Y & 11 & 0.004 & $19.453^{* * *}$ \\
\hline G x I & 22 & $0.135^{* *}$ & $1.622^{* *}$ \\
\hline Y x I & 2 & 0.006 & $18.769^{* *}$ \\
\hline G X Y X I & 22 & 0.005 & $3.645^{* *}$ \\
\hline Error & 198 & 0.017 & 0.736 \\
\hline
\end{tabular}

*,** Significant at 0.05 and 0.01 levels of probability, respectively . 
TABLE 2. Analysis of variance for stability of 12 sunflower genotypes for seed yield $(t /$ fed) and seed oil content $(\%)$ across six environments.

\begin{tabular}{|c|c|c|c|}
\hline Source of variation & d.f. & $\begin{array}{c}\text { Seed yield } \\
(\mathbf{t} / \mathbf{f e d})\end{array}$ & $\begin{array}{c}\text { Seed oil } \\
\text { content }(\%)\end{array}$ \\
\hline Model & 71 & $0.122^{* *}$ & $11.789^{* * *}$ \\
\hline Genotype (G) & 11 & $0.333^{* *}$ & $61.294^{* *}$ \\
\hline Environment (E) & 5 & $0.850^{* *}$ & $17.944^{* *}$ \\
\hline G x E & 55 & $0.014^{* *}$ & $1.329^{* *}$ \\
\hline E + G x E & 60 & $0.084^{* *}$ & $2.713^{* *}$ \\
\hline Env. (linear) & 1 & $4.252^{* *}$ & $89.722^{* * *}$ \\
\hline G x E (linear) & 11 & $0.054^{* *}$ & $0.913^{* *}$ \\
\hline Pooled deviation & 48 & 0.004 & 1.313 \\
\hline Pooled Error & 216 & 0.004 & 0.184 \\
\hline
\end{tabular}

*,** Significant at 0.05 and 0.01 levels of probability, respectively .

The estimates of phenotypic, genotypic and AMMI stability parameters have been computed for testing twelve sunflower genotypes grown under six environments for seed yield and seed oil content \% (Table 3). The regression " b" value deviated significantly from unity (b>) in sunflower genotypes L19, L990, L8 and Giza 102 for seed yield/fed as well as L235, L11, L460 and Giza 102 for seed oil content \% (Fig.1-A). Therefore, these sunflower genotypes could be grown under favorable environments. Otherwise, the " $b$ " value was significantly less than unity $(b<1)$ in L38, L350, L11, L770 and Sakha 53 for seed yield / fed as well as L770 and L8 for seed oil contents \% (Fig.1-A). These genotypes are suitable for drought stress environment. Concerning the deviation from linear regression $\left(\mathrm{S}^{2} \mathrm{~d}\right)$, it was very small and insignificant in all sunflower genotypes for all studied characters, except genotypes L38 for seed yield ( $\mathrm{t} / \mathrm{fed}$ ), as well as L38, L19, L235, L11 and L460 for seed oil content \%, which exhibited significant values of $S^{2}$. Thus, the genotypes having insignificant values of $S^{2} d$ were more stable. A simultaneous consideration of the three stability parameters, ( $\overline{\mathrm{X}}, \mathrm{b}$ and $\mathrm{S}^{2} \mathrm{~d}$ ), it can be seen that, the most desired and stable genotypes were L20, L235 and L460 for seed yield / fed and L20, L350 and Sakha 53 for seed oil content.

With regard to the genotypic stability, genotype $\mathrm{x}$ environment (GxE)interaction effect of a genotype was partitioned into two components; i.e. " $\alpha$ " statistic which measures the linear response to environmental effects and " $\lambda$ " statistic determines the deviation from linear response. A perfectly stable variety has $\alpha=-1, \lambda=1$. However the average stable variety has $\alpha=0, \lambda=1$. Whereas, the above average stable genotype should have an estimate of $\alpha<0$ and $\lambda=1$, however the value $\alpha>0$ and $\lambda=1$ described as below average stable one.

Results given in Table 3 and Fig. 1-B showed that the most tested genotypes were stable and insignificant for linear response to environmental effects $(\alpha)$ and the deviation from linear $(\lambda)$. As given in Table 3 and illustrated in Fig. 1-B , the average stability area contained sunflower genotypes L20 for seed yield /fed and L350, L770, L460 and Sakha 53 for seed oil content, they recorded an statistic Egypt. J. Agron. 34, No. 2 (2012) 
$\alpha=0$ and $\lambda=1$. Meanwhile, the below average stability area contained sunflower genotypes L 19, L990 and Giza 102 for seed yield (t/fed). These genotypes exhibited an estimate of $\alpha>0$ and $\lambda=1$. Moreover, the above average stable genotypes were L38, L350, L770 and Sakha 53 for seed yield / fed and L350 and L770 for seed oil content $\%$. They exhibited $\alpha<0$ and $\lambda=1$.

The additive main effects and multiplicative interaction model combines the analysis of variance for the genotype and environment main effects with the principal components analysis of the G $x$ E. A genotype with the smaller AMMI Stability value (ASV) is considered as more stable. The analysis of variance (Table 4) revealed that environment $(\mathrm{E})$, genotype $(\mathrm{G})$ and $\mathrm{G} \times \mathrm{E}$ mean squares were significant for seed yield ( $t / f e d)$ and seed oil content $(\%)$. Interaction principle component analysis (IPCA) scores of a genotype were significant for IPCA1 for seed yield (t/fed) and IPCA 1, IPCA2, IPCA3 and IPCA4 for seed oil content $(\%)$. Variance component percentages of sunflower genotypes were 38.15 for seed yield (t/fed) and $75.28 \%$ seed oil content $(\%)$. Whereas, variance component percentages due to environments were $44.32 \%$ and $10.02 \%$, in the same respective order. The IPCA 1 exhibited the highest component of variance, since it represents $86.5 \%$ for seed yield/fed and $75.29 \%$ for seed oil content $\%$, followed by the other scores (Fig.1-C). According to the ASV ranking (Table 3 and Fig. 1-C), the most stable sunflower genotypes are L20, L460 and L235 for seed yield (t/fed). As well as Giza102, L235 and L350 for seed oil content \%, while, the remaining sunflower genotypes exhibited different degrees of instability.

From the previous results, it could be mentioned that there were agreement between Eberhart \& Russell statistics with AMMI for measuring stability in genotypes L20, L235 and L460 for seed yield (t/fed) and L350 and Sakha 53 for seed oil $\%$. The two stability procedures were equivalent for measuring stability in the previous cases. Meantime, there was harmony between Tai (1971) procedure and AMMI for estimating stability in sunflower genotypes L20 for seed yield, and L350 as well as Giza 102 for seed oil content ((\%). Also, strong agreement has been detected between Eberhart \& Russell and Tai procedures for measuring stability in sunflower genotypes L20 and L460 for seed yield (t/fed) as well as L350 and Sakha 53 for seed oil content.

\section{Discussions}

The (GE) interaction reduces association between phenotypic and genotypic values and lead to bias in the estimates of gene effects for the various characters sensitive to environmental fluctuations, such traits are less amenable to selection. Both yield and stability of performance should be considered simultaneously to reduce the effect of GE and to make selection of genotype more precise and refined (Farshadfar et al., 2011). 


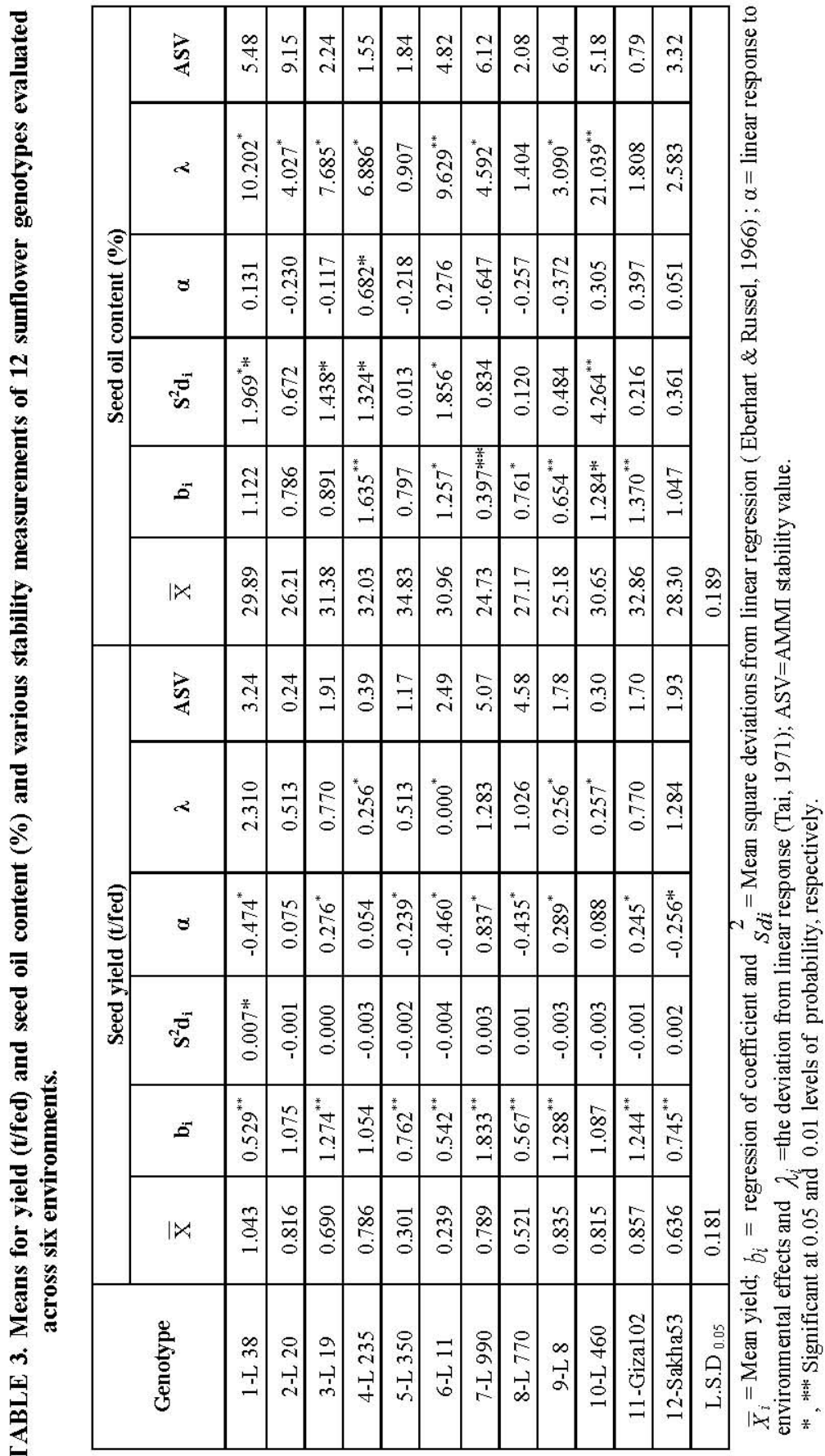

Egypt. J. Agron. 34, No. 2 (2012) 


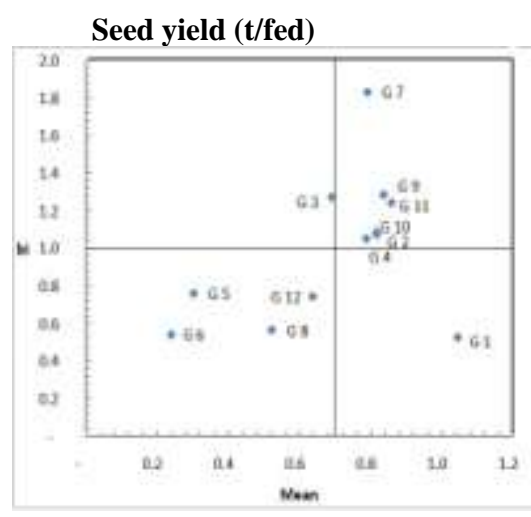

Seed yield (t/fed)

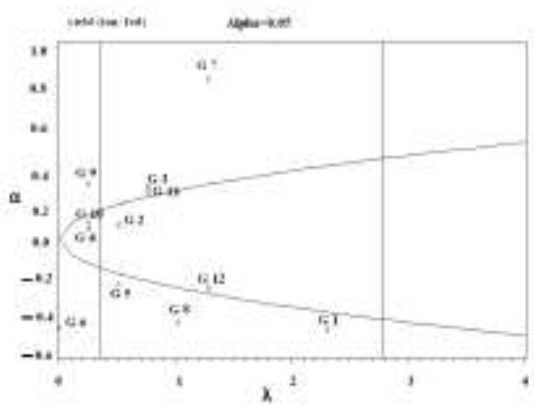

Seed yield $(\mathrm{t} / \mathrm{fed})$

AMMI biplot for yield (ton/ fad) using adjusted means

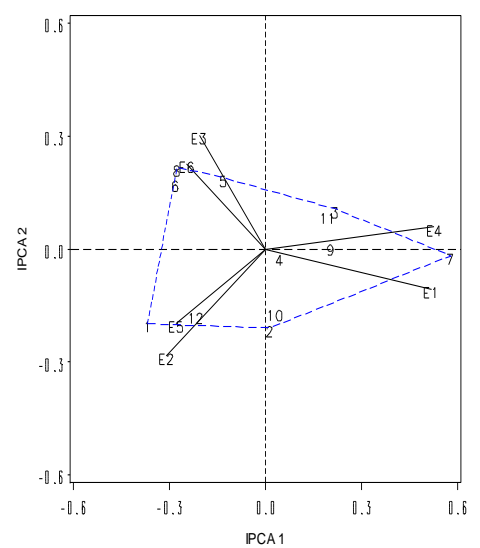

Seed oil content $(\%)$

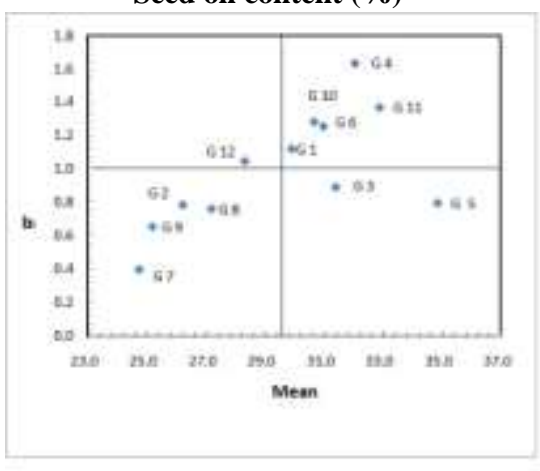

(A)

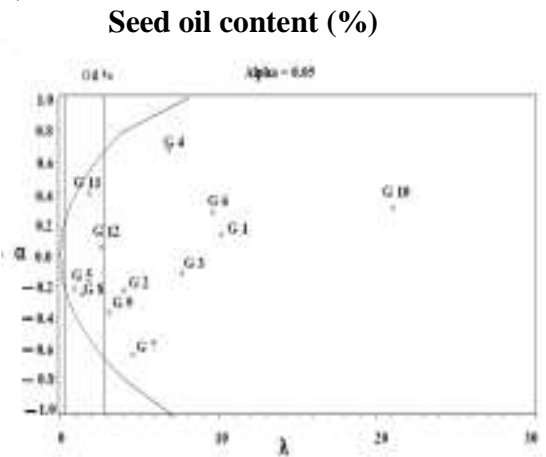

(B)

Seed oil content (\%)

AMMI biplot for oil\% using adjusted means

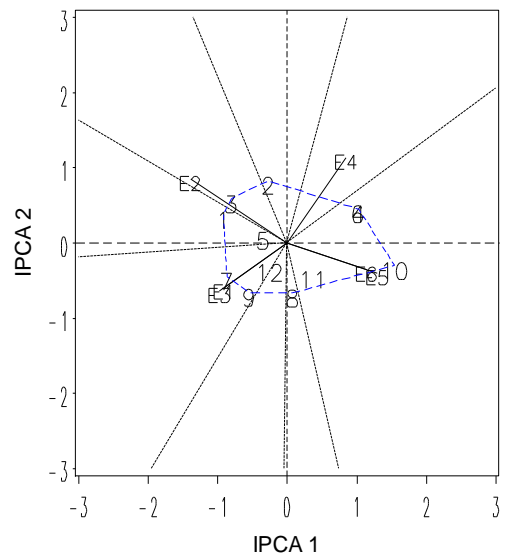

(C)

Fig.1. Illustration of stability parameters for seed yield (t/fed) and oil content $(\%)$ of sunflower genotypes using Eberhart \& Russell (A), Tai (B) and AMMI (C) models.

Egypt. J. Agron. 34, No. 2 (2012) 
TABLE 4. Mean squares (M.S.) from AMMI analysis for yield ( $t /$ fed) and seed oil content $(\%)$ of 12 sunflower genotypes across 6 environments.

\begin{tabular}{|c|c|c|c|c|c|c|c|}
\hline \multirow{2}{*}{$\begin{array}{c}\text { Source of } \\
\text { variation }\end{array}$} & \multirow{2}{*}{ d.f. } & \multicolumn{3}{|c|}{ Seed yield (t/fed) } & \multicolumn{3}{c|}{ Seed oil content (\%) } \\
\cline { 3 - 8 } & & S.S. & M.S. & \% & S.S. & M.S. & \% \\
\hline Environment (E) & 5 & 17.009 & $3.402^{* *}$ & 44.32 & 358.887 & $71.777^{* *}$ & 10.02 \\
\hline Reps / Env. & 18 & 0.279 & 0.016 & 0.73 & 88.698 & $4.928^{* * *}$ & 2.48 \\
\hline Genotype (G) & 11 & 14.641 & $1.331^{* *}$ & 38.15 & 2696.940 & $245.176^{* *}$ & 75.28 \\
\hline G x E & 55 & 3.102 & $0.056^{*}$ & 8.08 & 292.321 & $5.315^{* * *}$ & 8.16 \\
\hline IPCA1 & 15 & 2.686 & $0.179^{* *}$ & 86.50 & 220.094 & $14.673^{* *}$ & 75.29 \\
\hline IPCA2 & 13 & 0.306 & 0.024 & 9.85 & 37.052 & $2.850^{* *}$ & 12.68 \\
\hline IPCA3 & 11 & 0.075 & 0.007 & 2.41 & 20.643 & $1.877^{*}$ & 7.06 \\
\hline IPCA4 & 9 & 0.026 & 0.003 & 0.82 & 14.177 & $1.575^{*}$ & 4.85 \\
\hline IPCA5 & 7 & 0.013 & 0.002 & 0.41 & 0.357 & 0.051 & 0.12 \\
\hline Pooled error & 198 & 3.342 & 0.017 & & 145.769 & 0.736 & \\
\hline Total & 287 & 38.37 & & & 3582.62 & & \\
\hline
\end{tabular}

*** Significant at 0.05 and 0.01 levels of probability, respectively .

Multi-environmental sunflower field trials were conducted to compare efficiency of regression analysis, Tai's stability and AMMI model statistics to classify sunflower genotypes based on the stability of their performances for seed yield and seed oil content. It is commonly observed the differential response of sunflower genotypes to seasons and various levels of water supply. The differential response of genotype to environmental changes is a genotype by environment (GE) (Vargas et al., 2001). The GE linear was highly significant for seed yield and oil content, revealing differences in linear response among genotypes across the six environments (two years $\times$ three levels of water supply). In this connection, significant GE for sunflower characters was detected by Ghafoor et al. (2005), Ali et al. (2006) and Tabrizi (2012). The regression analysis proposed by Eberhart \& Russell (1966) was used to estimate linear regression (b) and the mean square deviation from regression $\left(S^{2} d\right)$. The linear regression (b) shows the response of a genotype to varying environments, while $\mathrm{S}^{2} \mathrm{~d}$ measures the dispersion around the regression line. Genotype with (b) value not significantly different from unity and $S^{2} d$ not significantly from zero or small as possible is considered as stable genotype. A stable genotype will be more desirable when it has a mean yield greater than the average yield of all genotypes. In this research, regression coefficients ranged from 0.529 (L38) to 1.833 (L990) for seed yield and from 0.397 (L990) to 1.635 (L235) for seed oil content. This variation in regression coefficients indicated that sunflower genotypes have different responses to environmental changes. Similar finding was reported by Akcura et al. (2009), sunflower genotypes L8 and Giza 102 had regression coefficient significantly greater than unity with seed yield above grand mean. These genotypes are sensitive to environmental changes and would be recommended for cultivation under favorable environments only (when the adequate water supply). 
Current study revealed that sunflower genotypes L20 and L460 are considered to be stable and desirable due to (b) values did not deviate significantly from unity and $\mathrm{S}^{2} \mathrm{~d}$ not deviated from zero and they have greater yield than the average yield of all studied genotypes. Meantime, sunflower genotypes L20, L235 and L350 are considered the most desirable and stable genotypes for seed oil content. Similar finding was reported by Ali et al. (2006) who showed that sunflower genotype KNI exhibited stability in its performance for oil yield due to the mean above the grand mean and values of (b) and $S^{2} d$ non significantly different from unity and zero, respectively. Hayward \& Lawrence (1970) stated that the response to environment as measured by the regression parameter was found to be highly heritable and controlled by genes with additive effects. In addition the values of $S^{2} d$ seemed to be the best measure of stability (Guilan Yue et al., 1990 ).

Concerning genotypic stability, Tai (1971) partitioned GE interaction into two statistics which were estimated for each genotype separately. The first statistic is $(\alpha)$ that measures the linear response to environmental effects and the second is $(\lambda)$ that measures the deviation from linear response in terms of error variance magnitude. Tai's analysis also provides a method for obtaining the predication interval for $\alpha=0$ and confidence interval for $(\lambda)$ values, so that the genotypes can be distributed graphically in different stability regions of the Tai's plot. Accordingly the average stability area contained sunflower genotypes L20 for seed yield as well as L350, L770 and Sakha 53 for seed oil content. These results are in agreement with the finding of Ahmed \& Abdellah (2009).

The AMMI model is a hybrid analysis that incorporates the additive and multiplicative component of two ways data structure (Shafii \& Price, 1998). The additive portion is separated from interaction by analysis of variance. Then the principle components analysis (PCA), which provides a multiplicative model (Zobel et al., 1988 ) is applied to analyses the interaction effect from the additive model.

The AMMI method is used for three main purposes. Firstly, it provides an analytical tool for diagnoses (Gauch, 1988). Secondly, it summarizes patterns and relationships of genotypes and environments (Crossa et al., 1990). The third one is to improve the accuracy of yield estimates and consequently improve of the efficiency in selecting the best genotypes (Farshadfar et al ., 2011).

The results of AMMI analysis showed that 44.33 -and $10.02 \%$ of the total sum of squares were attributable to environment effects for seed yield and seed oil content, respectively. The large amount of sum of squares for environment indicated that the environments were diverse with large differences among environmental means, causing most of the variations in seed yield. Similar conclusion was reported by Mohammadi et al. (2007).

The IPCA exhibited the highest component of variances. It represents $86.5 \%$ for seed yield (t/fed) and $75.29 \%$ for seed oil content $(\%)$. Thus, the prediction 
assessment indicated that AMMI with only the first interaction principal component axis was the best productive model. In this connection, Zobel et al. (1988) as well as Mekonnen \& Mohammed (2010) indicated that AMMI with only two interaction principal component axis was the best productive model. Moreover, Farshadfar et al. (2011) reported that IPCA1 score contributed more to GE sum of square which confirm the results obtained herein. Further interaction principal component axis captured mostly noise and did not help to predict validation of observations. Thus, the interaction among the twelve sunflower genotypes with six environments was the best predicted by the first interaction principal component of genotypes and environments. Genotypes with first principal-component axis value close to zero indicate general adaptation to environments. A genotype is regarded as stable if its first and second correspondence-analysis scores are near zero (Kang, 2002).

Stability value (ASV) is the distance from zero (the coordinate point to the origin) in a two dimensional scatter gram of IPCA1 scores against IPCA2 scores (Purchase et al., 2000). According to the ASV ranking the most stable sunflower genotypes were L20, L460 and L235 for seed yield as well as Giza 102, L235 and L350 for seed oil content. These genotypes had greater seed yield and oil content than the grand mean of the studied sunflower genotypes. Comparing the obtained results from the three stability models, it could be concluded that the most stable and desirable sunflower genotypes were L20 for seed yield and L350 for seed oil content in the three stability models.

Acknowledgment : The authors record their deepest gratitude and thanks to Zagazig University for providing facilities through funding the project titled: Improvement of sunflower for drought tolerance.

\section{References}

Ahmed, S.B.M. and Abdellah, A.W. (2009) Genetic yield stability in some sunflower (Helianthus annuus L.) hybrids under different environmental conditions of Sudan. J. of Plant Breeding and Crop Science, 1 (1), 16-21.

Akcura, M., Kaya, Y. and Taner, S. (2009) Evaluation of durum wheat genotypes using parametric and nonparametric stability statistics. Turkish J. of Field Crops, 14 (2), 111-122.

Ali, M.M.A (2009) Breeding studies on top crosses white and yellow maize (Zea mays L.). Ph.D. Thesis, Department of Agronomy, Faculty of Agriculture, Zagazig University.

Ali, S.S., Manzoor, Z., Awan, T.H. and Mehdi, S.S. (2006) Evaluation of performance and stability of sunflower genotypes against salinity stress. J. Anim. Pl. Sci. 16 (1-2), $47-51$.

AOAC (1984) "Official Method of Analysis", of the Association Official Analytical Chemist (AOAC) Washington D.C. USA, pp. 1250-1255.

Egypt. J. Agron. 34, No. 2 (2012) 
Awaad, H.A. and Ali, A.A. (2002) Genotype $x$ environment interaction and interrelationship among some stability statistics in sesame (Sesamum indicum L.). Zagazig J. Agric Res. 29 (2), 385-403.

Cravero, V., Martin, E., Anido, F.L. and Cointry, E. (2010) Stability through years in a non-balanced of globe artichoke varietal types. Scientia Horticulturae, 126 (2), 73-79.

Crossa, J. (1990) Statistical analyses of multilocation trials. Adv. Agron. 44, 55-85.

Crossa, J., Gauch, H.G. and Zobel, R.W. (1990) Additive main effect and multiplicative interaction analysis of two international maize cultivar trials. Corp Sci. 30, 493-500.

Eberhart, S.A. and Russel, W.W. (1966) Stability parameters for comparing varieties. Crop Science, 6, 36-40.

Farshadfar, E., Mahmodi, N. and Yaghotipoor, A. (2011) AMMI stability value and simultaneous of yield and yield stability in bread wheat (Triticum aestivum L.). Australian J.Crop Science, 5 (13), 1837-1844.

Gauch, H.G. (1988) Model selection and validation for yield trials with interaction. Biometrics, 44, 705-715.

Ghafoor, A., Arshad, I.A. and Muhammad, F. (2005) Stability and adaptability analysis in sunflower from eight locations in Pakistan. J. of Applied Science, 5 (1), 118-121.

Guilan Yue, Perng, S.K., Walter, T.L., Wassom,C.E. and Liang, G.H. (1990) Stability analysis of yield in maize, wheat, and sorghum and its implications in breeding programs. Plant Breeding, 104 (1), 72-80

Hayward, M.D. and Lawrence, T. (1970) The genetic control of variation in selected population of Lolium perenne L. Can. J. Cytol. 12, 806-815.

Iqbal, N., Ashraf, M.Y. and Azam, F. (2005) Effect of exogenous application of glycinebetaine on capitulum sixe and achene number of sunflower under water stress. International J. of Biology and Biotechnology, 2 (3), 765-771.

Kang, M.S. (2002) Genotype-environment interaction: Progress and prospects. In : "Quantitative Genetics, Genomics and Plant Breeding", M.S. Kang (Ed.) p . 221-243. CABI Publ., Wallingford, Oxon, UK.

Mekonnen, Z. and Mohammed, H. (2010) Study on genotype $x$ environment interaction of oil content in sesame (Sesamum indicum L). World J. of Fungal and Plant Biology, 1 (1), 15-20.

Mohammadi, R., Armion, M., Shabani, A. and Dargael, A. (2007) Identification of stability and adaptability in advances durum genotypes using AMMI analysis. Asian J. of Plant Sciences, 6 (8), 1261-1268. 
Purchase, J.L. (1997) Parametric analysis to describe genotype $\mathrm{x}$ environment interaction and yield stability in winter wheat. Ph.D Thesis, Department of Agronomy. Faculty of the Free State, Bloemfontein, South Africa.

Purchase, J.L., Heating, H. and Van Denever, C.S. (2000) Genotype x environment interaction of winter wheat (Triticum aestivum L.) . South African Journal of Plant and Soil, 17 (3), 95-100.

Rauf, S. (2008) Breeding sunflower (Helianthus annuus L.) for drought tolerance. Communications in Biometry and Crop Science, 3 (1), 29-44.

Schoeman, L.J. (2003) Genotype x environment interaction in sunflower (Helianthus annuus L.) in South Africa. Ph D Thesis, Department of Agronomy. Faculty of the Free State. Bioemfontein. South Africa.

Shafii, B. and Price, W.J. (1998) Analysis of genotype-by- environment interaction using the additive main effects and multiplicative interaction model and stability estimates. J. Agric. Biol. Environ. Stat. 3, 335-345.

Sial, M.M. and Arian M. Ahmad (2000) Genotype x environment interaction on bread wheat grown over multiple sites and years in Pakistan. Pakistan J. of Botany, 32 (1), 85-92.

Steel, R.G. and Torrie, J.H. (1980) "Principles and Procedures of Statistics". Mc Graw Hill, New York.

Tabrizi, H.Z. (2012) Genotype by environment interaction and oil yield stability analysis of six sunflower cultivars in Khoy, Iran. Advances in Environmental Biology, 6 (1), 227-231.

Tai, G.C.C. (1971) Genotypic stability analysis and it's application to potato regional trials. Crop Science, 11, 184-190.

Vargas, M., Crossa, J., van Eeuwijk, F., Sayre, K.D. and Reynolds, M.P. (2001) Interpreting treatment $\mathrm{x}$ environment interaction in agronomy trials. Agron. J. 93, 949-960.

Zobel, R.W., Wright, M.J. and Gauch, H.G. (1988) Statistical analysis of a yield trial. Agron. J. 80, 388-393. 


\section{بعض معسالم الثبـات لتراكيب دوار الثـمس الوراثيـة تحـت بيئسات

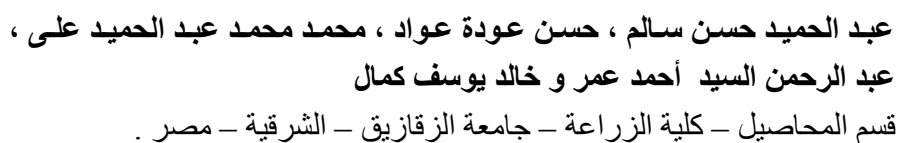

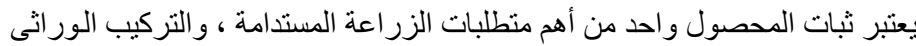

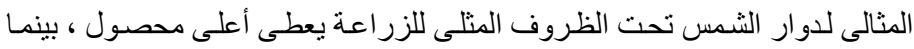

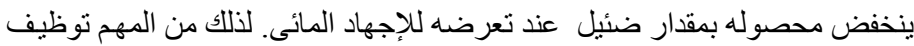

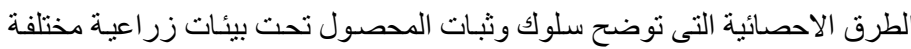

لانتخاب التر اكيب الور اثثية الأكثر ثباتا.

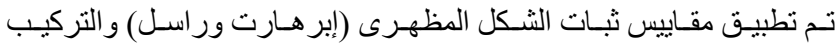

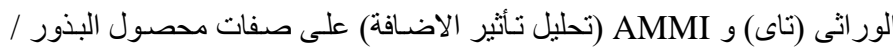

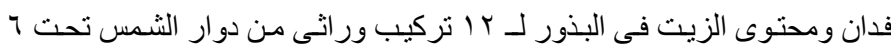

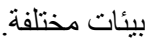

أظهرت النتائج وفقا لمقاييس ثبات الثكل المظهرى (إيرهارت وراسل) أن

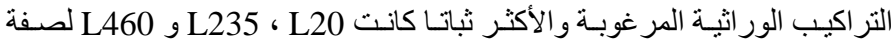

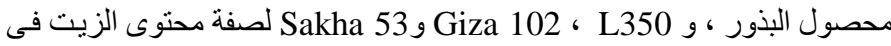

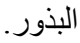

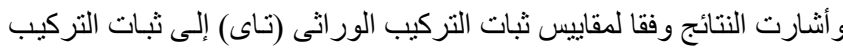

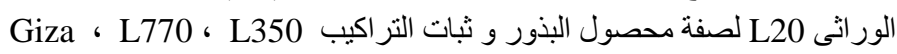

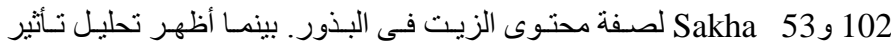

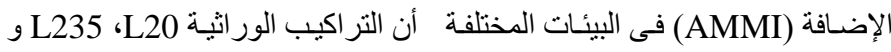

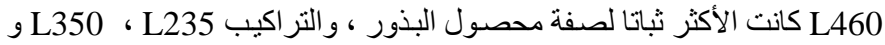

Giza 102

ومن النتائج المتحصل عليها يوجد نو افق قوى بين مقاييس الطرق الثالثاثة

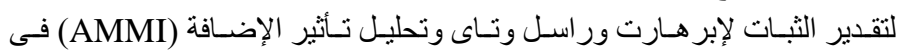

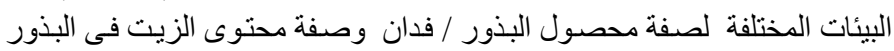

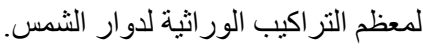

